\title{
BIOGAS UTILISATION IN NORWAY
}

\author{
Knut H. Birkeland \\ Energy System AS, Norway
}

\section{Intoduction}

Controlled production of biogas has no tradition in Norway. The country has been lucky to have renewable energy enough for its own consumption and some extra for export.

Traditionally people in Norway heat their houses with wood and electricity from hydropower. We are about 4 million people and even today we normally uses 800000 wood-burning stoves each day during the winter. Annually it is sold 40000 new such stoves (with a catalyzer).

After the 2.nd world war we were sure about that we had enough hydropower for all future we have waterfalls enough to meet increasing demands of electricity. New houses were built without chimneys and old houses turned out their waterbased systems. Each unit (flat, single family house/home) was heated separately with electricity - a clean, cheap and easy energy form to use.

Increasing interest of nature conservation results in actions against development of waterfalls to hydropower plants. The consumption of electricity increased so much that new power cables to the continent, meant for export mostly is used for import. (To day we import more electricity than we export). Unfortunately energy from fossil sources was cheap in this period so normal people, industry and commerce installed chimneys and oil burmers/heaters.

We produce enormous quantities of natural gas from the North Sea. Most of it is exported to the continent, but some of it is might be used at home. The authorities introduce two great gasfired powerstations to make us independent of energy from other nations (so far stopped because of $\mathrm{CO}_{2}$ ).

This is why district-heating systems was not built until these days in Norway.

\section{External conditions}

There are some conditions for introduction of biogas technology (4-e's):

- energy demand 
- excess of biomass in a small area

- environmental reasons

- economy

Up till today none of them has been reasons good enough for personal engagement, except for some waste water treatment plants and the potato industry. (We earlier had, - as mentioned in the introduction - enough cheap energy, a very decentralised farm structure, few people spread over a big country, few or no subsidies)

The leader of the Rio Convention, our earlier Prime Minister Gro Harlem Brundtland, promised that Norway should reduce their greenhouse gas emissions. Since we almost uses energy from clean hydro power for heat and light and it is (so far) impossible to reduce fossil fuels in the transport section, the authorities decided to reduce methane emissions by taking out the gas from our landfills and wet organic waste and do it effectively (biocells, cellreactors etc.). This will reduce our $\mathrm{CO}_{2}$ (as methane) emissions with $50 \%$ of Norway's contractual obligations compared with the Kyoto agreement.

This period taught us to handle and treat organic matter by different anaerobic digestion (AD) systems.

Last year the government decided that new renewable energy used as a substitute for fossil fuel, should be focused. To make an easy start they promised:

- increase investment contribution to 60000000 EURO (400 $000000 \mathrm{FRF}$ )/year (average over 10 years)

- possibility of long-term loans with low interest

- public buildings must be heated with water based systems

- wet organic fraction from obligate source separation must be treated

- extra tax on landfilled waste (40 EURO /260 FRF pr. tonn)

- electric current prodused by you self remains free from taxes.

Probably this will be that little push that is needed to introduce different types of biogas into the energy market.

\section{Biogas production}

Biogas is used as a common name for gases containing methane created by biological processes/activity from microorganisms. By practical reason biogas is divided into 3 different categories: 
- $\quad$ LFG - landfill gas

- Sewage gas

- AD-biogas, AD-reactor gas or only biogas

\section{LFG - landfill gas}

LFG consists of a gasmicture with less than $60 \%$ of methane $\mathrm{CH}_{4}$.

In Norway the first plant was constructed by us in $1982 / 83$, but was built in 1985 .

Most plants are built on authority demand - because of local and global environmental reasons. Public opinion is a main reason in many cases.

In the end of 1998 Norway have 45 LFG extraction plants. Most of them are built the last 3 years.

20 million tons of waste produces 73 million collected $\mathrm{Nm}^{3}$ LFG/year . Most landfills produce gas with more than $50 \%$ of methane, but a very few plants give about $35 \%$ and they lower the $\mathrm{CH}_{4} \%$.

The production is shown in table 1 .

Table 1. LFG production in Norway 1998

\begin{tabular}{|c|c|c|c|c|c|}
\hline LFG plants Waste & LFG & CH4 & Flared & Recovered \\
\hline number & mill. t & mill Nm3 & $\%$ & $\%$ & $\%$ \\
\hline 45 & 20 & 72,7 & 46,8 & 82 & 10 \\
\hline
\end{tabular}

Most of the gas ( $82 \%)$ is flared - only $10 \%$ is recovered.

Table 2 presents the energy from LFG in 1998.

Table 2. Energy from Norwegian landfills in 1998

\begin{tabular}{|c|c|c|c|}
\hline & LF G & Flared & Recovered \\
\hline GW H & 358 & 295 & 36 \\
\hline
\end{tabular}




\section{Waste water treatment plants}

We have $17 \mathrm{AD}$ wastewater treatment plants. All of them are mesofilic with a termofilic pretreatment stage.

Volumes vary from $400 \mathrm{~m}^{3}$ to $24000 \mathrm{~m}^{3}$ reactor volume. Retention time varies from 10 to 150 days.

Table 3 gives an average of data from our waste water plants and the "typical Norwegian plant".

Table 3 Biogas from Norwegian AD-reactors - 16 waste water treatment plants. Variations and the "Typical Norwegian Plant".

\begin{tabular}{|l|c|c|c|c|c|}
\hline & Energi & Volum & Retention time & TS & CH4 \\
\hline & GWh & m3 & days & \% & $\%$ \\
\hline Max & 25,7 & 24000 & 10 & 14 & 79 \\
\hline Min & 0,7 & 400 & 150 & 3 & 65 \\
\hline Typical & 2,7 & 1776 & 20 & 4,5 & 75 \\
\hline
\end{tabular}

Total production is about $80 \mathrm{GWh}$ pr. year. Most of the energy is used as process heat. 3 plants have CPH. 15 to $20 \%$ of the energy are flared during the summer. period.

\section{AD-reactors in agriculture and industry}

In addition to the plant mentioned, we have a very small reactor called Dagrosfeltet. The farmer uses cattle manure only and produces small "cow-cakes" in co-operation with a university (FoU). The "cakes" are used as a fertiliser and as a protection against damage from insects on some agriculture crops (e.g. cabbage).

The total energy production is about $65 \mathrm{GWh} /$ year.

Table 4 Norwegian AD-reactors in industry and agriculture - an overview

\begin{tabular}{|l|c|c|c|c|c|c|c|c|c|}
\hline \multicolumn{1}{|c|}{ Name } & Place & $\begin{array}{c}\text { No.: of } \\
\text { reactor- } \\
\text { tanks }\end{array}$ & $\begin{array}{c}\text { Volum } \\
\mathbf{e} \\
\mathbf{m}^{\mathbf{3}}\end{array}$ & $\begin{array}{c}\text { Temp } \\
{ }^{\circ} \mathrm{C}\end{array}$ & $\begin{array}{c}\text { Retention } \\
\text { time } \\
\text { days }\end{array}$ & $\begin{array}{c}\text { DM } \\
\text { input } \\
\%\end{array}$ & $\begin{array}{c}\mathbf{C H}_{\mathbf{4}} \\
\%\end{array}$ & $\begin{array}{c}\text { gas /year } \\
\mathbf{m}^{3}\end{array}$ & $\begin{array}{c}\text { Use of } \\
\text { energy }\end{array}$ \\
\hline Dagrosfeltet & Ørland & 1 & 50 & 56 & 21 & 8 & 46 & & $\begin{array}{c}\text { Manure } \\
\text { treatment }\end{array}$ \\
\hline Etnedal & Etnedal & 1 & 11 & & & & & & \\
\hline $\begin{array}{l}\text { Norske } \\
\text { Potetindu- } \\
\text { strier AL }\end{array}$ & Gjøvik & 1 & 1440 & 35,5 & $4-5$ & - & $70-$ & $120000 /$ & Flaring \\
\hline KIMS & Skreia & 2 & 652 & 35 & $\sim 2,5$ & $\sim 0,5$ & $\sim 80$ & $\sim 500000$ & Flaring \\
\hline Saugbruksf. & Halden & 1 & 1750 & & & & $\sim 75$ & 2300000 & Process \\
\hline Borregaard & Sarpsborg & 2 & 26380 & & & & $\sim 75$ & 5500000 & Process \\
\hline Årdal (?) & & & & & & & & & \\
\hline
\end{tabular}




\section{Biogas utilisation}

Energy is cheap in Norway, we have no subsidise for renewable energy and we have almost none district heating systems. Biogas utilisation up to now is not economically founded, but politically.

Everybody wants a car driven by biogas, electricity from biogas or products from biogas, but only a few are willing to pay for it.

Up to 1998 most of the produced biogas was flared. Figure 1 shows a typical Norwegian utilisation/recovery system. The graph shows that utilisation depends

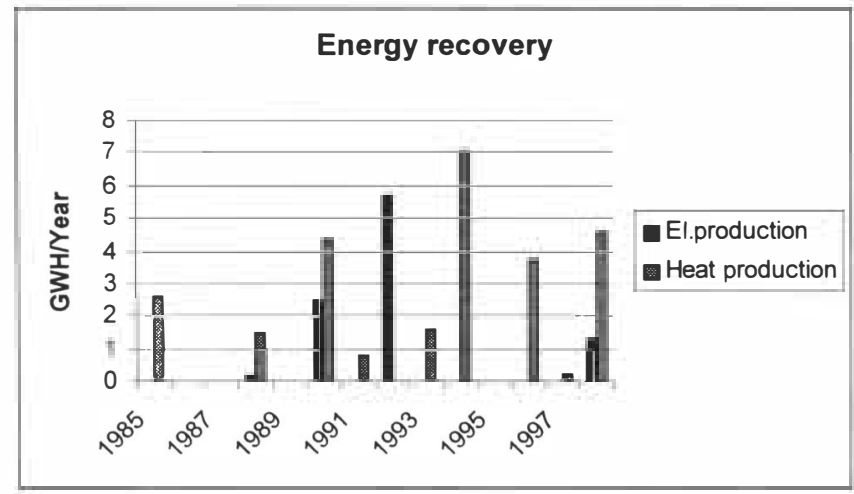

Figure 1. Energy recovery from Norwegian landfills listed after the year the recovery started

on special situations like personal or political engagement. There is not a continuos predictable situation.

The situation seems a little better if we summarise the energy production year by year. The figure tells (as seen in figure ) that production of electricity was introduced about 1993 and stopped with that. Heat seems to be the common way to use energy from LFG. 


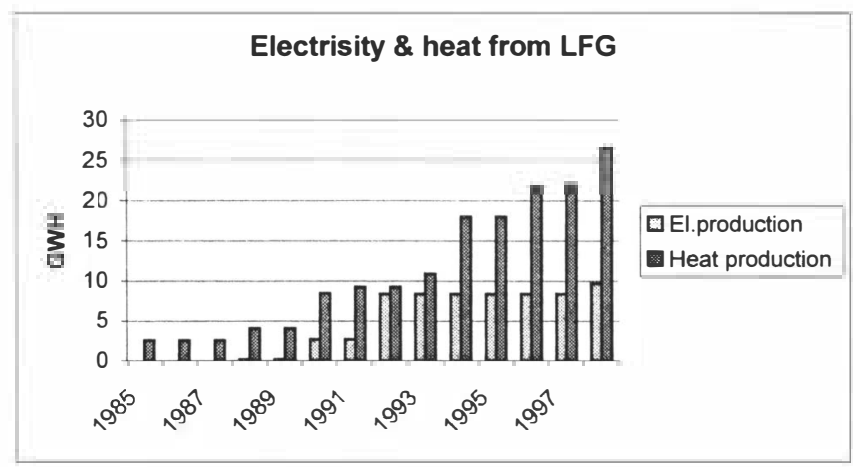

Figure 2. Energy produced from LFG in Norway from 1985 - 1998

\section{9 seems to be the year where things change.}

All the initiatives mentioned from the government, the fact that energyprices are increasing even in Norway, people's ideas about environment, a new generation growing up, EU directives and the press from initiators, associations etc. seems to give us a new time for biogas production and utilisation.

The old way of landfilling is more or less out. The landfills are going to be "privatised" by law. That means that they must earn their own money - it is not allowed to "mix with" other municipal money or taxes. To day we think: Best way to handle waste and earn money from it.

I will give you 2 examples from handling Wet organic waste:

\section{Example I}

A farmer with a grown up son that wants to take over the farm:

Data: 40 ha crop land and 500 ton manure/year (cattle)

The farmer has from earlier a liquid-manure tank of $1000 \mathrm{~m}^{3}$

The farmer built

- a simple concrete tank with a heating coil and a home-made stirrer $-100 \mathrm{~m}^{3}$

- A concrete pre-treatment tank $-40 \mathrm{~m}^{3}$

- A nice building for the reactor

The process is termofile $-55^{\circ} \mathrm{C}$, loading once a day. 


\begin{tabular}{|l|l|}
\hline \multicolumn{1}{|c|}{ Financing } & EURO \\
\hline Total cost & $\mathbf{5 9 0 0 0}$ \\
\hline Subsidy & 36000 \\
\hline Own capital & 23000 \\
\hline
\end{tabular}

He will start with only his own manure $500 \mathrm{t} / \mathrm{y}+500 \mathrm{t} / \mathrm{y}$ of wet organic fraction:

\begin{tabular}{|l|c|}
\hline \multicolumn{1}{|c|}{$\mathbf{5 0 0}$ ty Wet Organic } & EURO \\
\hline Income & $\mathbf{2 2 6 0 0}$ \\
\hline Electricity & -600 \\
\hline Capital depreciation & -4200 \\
\hline Income from work & $\mathbf{1 7 8 0 0}$ \\
\hline
\end{tabular}

Gradually he will increase the wet organic fraction up to $1500 \mathrm{t} / \mathrm{y}+$ his own manure $500 \mathrm{t} / \mathrm{y}$.

\begin{tabular}{|l|c|}
\hline \multicolumn{1}{|c|}{$\mathbf{1 5 0 0}$ t/y Wet Organic } & EURO \\
\hline Income & $\mathbf{6 8 0 0 0}$ \\
\hline Electricity & -1500 \\
\hline Capital depreciation & -6000 \\
\hline Income from work & $\mathbf{6 0 5 0 0}$ \\
\hline
\end{tabular}

If this works well, he probably will use the biogas for heat and power production (CPH).

Picture 1 Reactor

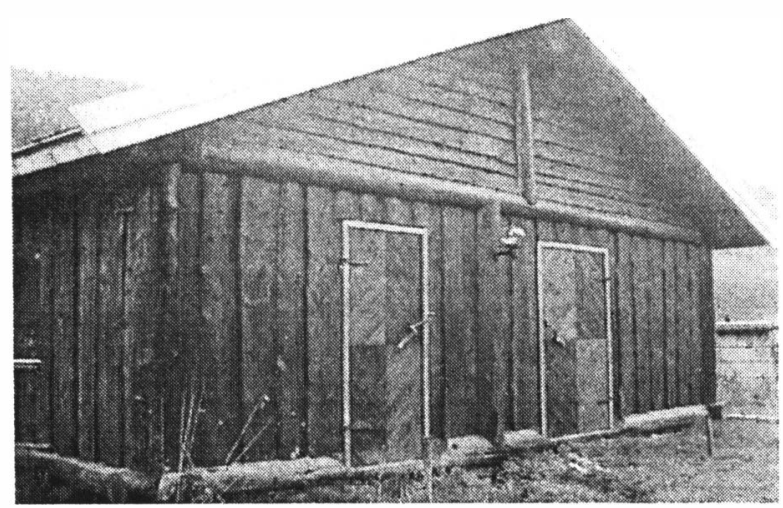

Example II

20000 tons of household waste with wet organic fraction was collected for incineration. Because of circumstances it was impossible. My company in co-operation with J.E. Meyer (Sweden) constructed a bio-cell to handle it. The biogasproduction after 5 months indicate that the cell will be bumed out in 3-4 years. This treatment was so successful that some more has been built/are under construction. 


\section{Example III}

After building some reactorcells on different matter, we decided to build 9 cells for treatment of clean wet organic waste. The first cell has worked for 14 days and seems to function the way we wanted after a lot of practical problems. This reactorcell is a project worked out together with the University of Luleå and my companies (Biogas as and Energisystemer as).

In Norway we have about 10 million $\mathrm{m}^{3}$ of "collected" manure and about $800000 \mathrm{t}$ wet organic/year so it should be possible to built some more AD-reactors.

So far this year it is decided to install:

1. one CPH-plant 3,6 MW el. and $7 \mathrm{MW}$ heat on LFG

2. one CHP-plant 2,5 MW el and $5 \mathrm{MW}$ heat on LFG combined with AD-reactorgas

3. one CHP-plant $0,7 \mathrm{MW}$ el and $1 \mathrm{MW}$ heat on LFG

4. one CHP-plant $0,7 \mathrm{MW}$ el and $1 \mathrm{MW}$ heat on combined LFG and AD-reactorgas

5. one CHP-plant on $0,01 \mathrm{MW}$ el and $0,03 \mathrm{MW}$ heat on AD-reactorgas.

Most of the installations are container solutions. The pictures show containers from the leading producer in Europe: G.A.S. Energietechnik GmbH, Germany. They have delivered over 500 plants on biogas. We have studied them very well and likes what we have seen. Biogas AS is from 1999 their agent in Scandinavia and the Baltic States.

Other utilisation solutions have been discussed. A special group (big industries and consultant companies) has had a few meetings to "brainstorm" new ideas. Time will show what came out of this discussion.

\section{References}

Birkeland, Knut "Biogas in Norway", Réseaux Européen AD Nett et Waste for Energy Biogas "la méthanisation des déchets organiques en zone rurale", Toulouse, France 1999

Birkeland, Knut "Biogass i Norge”, Nordisk Biogaskonferens 2.-3. 10 1996, Helsingborg, Sweden - The Swedish Biogas Association.

Birkeland, Knut "LFG - Landfill Gas in Nordic Countries" Seminar on Waste Management and the Environment, Nov. 5 to 7, 1997 - Kalmar Sweden

Thomsen, Jan Statens Miljøfond, Dagens Næringsliv 18.08.99, Nor way 